\title{
Development Aid: A Perspective on the World Bank Performance Calculating the Social Return on Investment for the Least Developed Countries
}

\author{
Dominik Schäfer \\ Correspondence: Dr. Dominik Schäfer, HHL Leipzig Graduate School of Management, Jahnallee 59, 04109 Leipzig, \\ Germany.
}

Received: September 2, 2016

doi:10.11114/bms.v3i1.2242
Accepted: February 21, 2017

Online Published: February 23, 2017

URL: https://doi.org/10.11114/bms.v3i1.2242

\begin{abstract}
This paper focuses on the evaluation of the World Bank (WB) performance in delivering development aid to the Least Developed Countries (LDCs). The portfolio Net Present Value (NPV) at the result stage of the LDCs (168 projects) was positive with NPV values ranging from 42,059 to 50,779 Mio USD (33,506 Mio USD total project costs) and from 6,188 to 7,799 Mio USD excluding the 7 outlier projects with abnormally "high-value" NPVs. The minimum Social Return on Investment (SROI) of the LDCs including all project costs was calculated. This SROI ratio outcomes of 1 and 1.06 in the weighted and 1.3 and 1.72 in the unweighted case indicate that projects delivered by the WB have a positive effect on the poor countries.
\end{abstract}

Keywords: NPV, Net Present Value, Present Value, World Bank, WB, World Bank Performance, Social Return on Investment, SROI, Millennium Development Goals, MDG, MDGs, Least Developed Countries, LDC, LDCs

\section{List of Abbreviations}

$\begin{array}{ll}\text { CAS } & \text { Country Assistance Strategy } \\ \text { EVI } & \text { Economic Vulnerability Index } \\ \text { GDP } & \text { Gross Domestic Product } \\ \text { GNI } & \text { Gross National Income } \\ \text { GNP } & \text { Gross National Product } \\ \text { HAI } & \text { Human Assets Index } \\ \text { IBRD } & \text { International Bank for Reconstruction and Development } \\ \text { ICR } & \text { Implementation Completion and Results (Report) } \\ \text { IDA } & \text { International Development Association } \\ \text { IEG } & \text { Independent Evaluation Group } \\ \text { IMF } & \text { International Monetary Fund } \\ \text { LDCs } & \text { Least Developed Countries } \\ \text { MDGs } & \text { Millennium Development Goals } \\ \text { NPV } & \text { Net Present Value } \\ \text { ODA } & \text { Official Development Assistance } \\ \text { PV } & \text { Present Value } \\ \text { RR } & \text { Rate of Return } \\ \text { SROI } & \text { Social Return on Investment } \\ \text { ROI } & \text { Return on Investment } \\ \text { UN } & \text { United Nations } \\ \text { UNICEF } & \text { United Nations Children's Fund } \\ \text { WB } & \text { World Bank } \\ \text { WBG } & \text { World Bank Group } \\ \text { WHO } & \text { World Health Organization }\end{array}$




\section{Introduction}

\subsection{Introduction to the Topic}

Over the course of the last 2 centuries, global prosperity has accelerated and each generation has been encouraged to meet new challenges to "make the world better" by lifting up human well-being. Nevertheless, the picture does not look promising everywhere (Easterley (2006), p. 7; Sachs (2005), p. 360).

According to experts, there are 10 significant challenges within the global poverty context: air pollution, conflict, disease, global warming, education, sanitation and water, malnutrition and hunger, trade barriers and subsidies, women, and development and terrorism (Lomborg (2009), p. 2). To address global poverty problems and help the poorest billion improve their situations, many development aid organizations and so called human aid institutions have arisen, particularly in the last few decades (Easterley (2008)).

The new millennium has also offered prospective hope in solving global prosperity problems through emerging technologies as part of the ongoing IT boom and the continued economic progress in China, India, and Russia. Although Africa is still in a miserable crisis, a spread of democracy throughout the continent has given hope to the possibility of activating processes to use new technologies to fight different diseases. The most vivid reflection of this was the Millennium Assembly which took place at the United Nations (UN) in New York. It was the largest assembly of world leaders in history with 147 heads of state and government attending. For this occasion, UN Secretary-General Kofi Annan presented the document "We the Peoples: The Role of the United Nations in the $21^{\text {st }}$ Century", laying out a critical view of the global challenges of our time, such as extreme poverty, environmental damage, major disease problems, civil conflicts and war. This document became the basis for the Millennium Declaration which sets forth a series of time-bound and quantified goals, the Millennium Development Goals (MDGs).

In general, there are some common ideas and agreements on how to start immediately with foreign aid solutions, regardless of the opposing opinions on how to apply Official Development Assistance (ODA) most efficiently (Easterly (2006); Sachs (2005), p. 210 et seq.; Schabbel (2006), p. 281 et seq.):

- Promotion of understanding ODA as a subsidy

- Grants instead of loans

- Differentiated diagnoses according to the country specific needs by shifting from supply to demand focus

- Competitive advantages and accountabilities of aid agencies

\subsection{Millennium Development Goals}

The MDGs were unanimously agreed by the $191 \mathrm{UN}$ member states that culminated in the signing of the United Nations Millennium Declaration in 2002. In principle, these goals stand for the main objectives of our endeavors to solve world poverty problems and gain global prosperity (Easterly (2006), p. 8; Sachs (2005), p. 25; United Nations Development Programme (2011): Millennium Development Goals).

Today, the 8 MDGs are broken further down into 21 quantifiable targets that are measured by 60 indicators. To ensure that the MDGs can be achieved and to put a realistic plan into place, the UN Millennium Project was founded in 2002. The project was engaged by 250 central global expert participants who represented each part of the entire UN system (World Health Organization (WHO), United Nations Children's Fund (UNICEF), the Food and Agriculture Organization, The United Nations Environment Program, etc.). In order to estimate the total amount of foreign aid available through the MDGs, each country must first offer a detailed costing plan based on the Millennium Project methodology. This has been outlined by a minimum amount of 135 to 195 billion USD per year for the period of 2005 through 2015 (this is about 0.44 to 0.54 percent of the rich-world Gross National Product (GNP) each year). Based on the official calculations from 2005/06 and the MDGs Summit outcome in 2010, this means that ODA would need to be more than doubled for the majority of the Least Developed Countries (LDCs) to reach the MDGs and for poverty to be halved by 2015 (Sachs (2005), p. 223 et sqq.; United Nations Development Programme (2011): The 2010 MDG Summit Outcome).

Looking at the fact sheets of the single MDGs, the progress towards reaching them is good, but not sufficient in order to completely achieve the full scope for each one of them on time.

On 25 September 2013, the president of the UN General Assembly hosted a special event in order to follow up on the efforts made towards achieving the MDGs. At this special event UN Secretary-General Ban Ki-moon presented to member states his report entitled "A Life of Dignity for All". This document was adopted by the member states, and herein the world leaders renewed their commitment to meet the MDG's targets and goals (Ahrens (2005); Easterley (2006), p. 24; Köhler et al. (1996)). 


\section{Research Approach}

In this chapter, the research objective and relevant terms, definitions, and methods are explained in detail. Furthermore, the structure of this paper, the data set used as a research basis, and the conclusive findings are also presented and discussed.

\subsection{Objective}

The purpose of this research project is to establish an evaluation approach for assessing the (economic) performance of development aid. In order to do so, NPV outcomes are evaluated. The data set upon which these analyses shall be based is sourced from the Implementation Completion and Results (ICR) Reports of the WB. As a central element the SROI concept will be discussed within this research paper. The idea is to calculate the SROI ratio of the LDCs based on development aid's direct market values.

\subsection{Structure}

After a short introduction to the topic the second chapter the research approach itself is presented to set the basic understanding for this paper, and the objective and structure of this paper are further defined. Furthermore, important facts on the WB, the data access and relevance of it and the term performance are given. Chapter 3 focuses on the theoretical foundations of the NPV calculation and the SROI concept. In the fourth chapter the result NPV values of the LDCs are presented and the calculation of the minimum SROI ratio is conducted. The final chapter then summarizes and concludes this research project.

\subsection{Least Developed Countries}

The categorization of LDCs $^{1}$ was created by the UN Economic and Social Council through its Committee for Development Policy in 1971. Currently $49^{2}$ developing countries from Africa (34 countries), Asia (14 countries) and Latin America (LA; 1 country) are classified as least developed by having a low level of per capita income and human resource development and a high degree of economic vulnerability. The following criteria which were revisted by the Committee in 2012 during the triennial review, apply to all LDCs (Least Developed Countries (2014); UNCTAD (2014): Data on Least Developed Countries):

1. Low-income criterion: based on a 3-year average estimate of the gross national income (GNI) per capita.

2. Human Asset Index (HAI) - based on indicators of nutrition, health, education and adult leterarcy rate.

3. Economic Vulnerability Index $(\mathrm{EV})$ - based on indicators of population size, remoteness, merchandise export concentrationshare of agriculture, forestry and fisheries in gross domestic product, share of population living in low elevated coastal zones, instability of exports of goods and services, victims of natural disasters and instability of agricultural production.

In order for a country to be defined as a LDC all of the following critera have to be met:

- GNI Per Capita: 992 USD or less

- HAI: 60 or less

- EVI: 36 or more

As per an evalutation by the UN, the annual gross domestic product (GDP) per capita for LDCs amounted to 684 USD on average (Least Developed Countries (2014); UNCTAD (2014): Data on Least Developed Countries).

In order for a country to graduated out of the LDC status, 2 of the following 3 critera must be met (Least Developed Countries (2014): A country also qualifies for graduation if its GNI per capita is 2,380 USD or more, independent of its HAI and EVI scores):

- GNI Per Capita: 1,190 USD or more

- HAI: 66 or more

- $\quad$ EVI: 32 or less

All LDCs have adopted special support measures in order to recognize and monitor their particular problems.

The LDCs benefit from differential treatment in international economic and financial relations, such as market access

\footnotetext{
${ }^{1}$ Author's Note: In principal, there have been 3 country groups identified by the UN which face specific development challenges: a) the LDCs itself, b) Land-locked Developing Countries and c) Small Island Developing States. However, subject to this paper are the LDCs only.
}

${ }^{2}$ Author's Note: South Sudan became a LDC in 2012. 
preferences and priorities in terms of technical assistance by donor nations. All measures are designed to overcome structural disadvantages, support physical infrastructure development, develop human resources, and strengthen institutional capacities. The overarching goal is to eradicate poverty and achieve the agreed development goals in order to move out of the LDC category (UNCTAD (2014): Data on Least Developed Countries).

\subsection{World Bank}

The WB is one of the largest global financial institutions that serves as a vital source of financial and technical assistance providing funds (most of all loans respectively credits) to developing countries for capital programs. It is not a bank in the ordinary sense but a unique partnership and global union to reduce poverty and support development. The WB was created at the Bretton Woods Conference in New Hampshire (US) in 1944 and became operational on the $27^{\text {th }}$ of December in 1945. Along with it, International Monetary Fund (IMF) was also established. Since July $1^{\text {st }}$ in 2012 Jim Yong Kim is the $12^{\text {th }}$ president leading the WB.

The underlying objective of the WB and its operations is to increase productivity, incomes and welfare ("standard of living"). Furthermore, wages and employment should be raised and the working conditions, such as the conditions of labor, in the territories of member countries should be improved (WB (2014): About; WB (2015): IEG - Cost-benefit Analysis in World Bank Projects; WB (2014): What we do).

The WB itself must not be confused with the World Bank Group (WBG) which is a member of the UN. The Group consists of 5 international organizations which all supply funds to the LDCs (WB (2014): About; WB (2014): What we do):

- International Bank for Reconstruction and Development (IBRD)

- International Development Association (IDA)

- International Finance Corporation (IFC)

- Multilateral Investment Guarantee Agency (MIGA)

- International Centre for Settlement of Investment Disputes (ICSID)

The WB comprises only the first 2 institutions mentioned, namely the IBRD and the IDA. Today, 188 countries are part of the IBRD and 172 of the IDA institutions (WB (2014): About).

In general, the WBG is aiming to achieve the following 2 goals for the world by the year 2030 (WB (2014): What we do):

- End extreme poverty by decreasing the percentage of people living on less than 1.25 USD a day to no more than 3 percent.

- Promote shared prosperity by fostering the income growth of the bottom 40 percent for every country.

\subsection{Data Access and Relevance}

This chapter deals with the data set used for this research project and thus provides an overview of the data access and details on the collection of the ICR reports. Afterwards the ICR reports and their content are highlighted before further details on the various project types available conclude this chapter.

\subsubsection{Data Basis}

Research data used for this paper was obtained from ICR documents published by the WB on the bank's homepage. Audiences of this data set are governments, beneficiaries amongst individual countries and around the globe as well as the general public (WB (2012)). As explained in the previous chapter, the WB and its institutions are key supporters for addressing and solving the world's poverty problems. For this reason and considering the importance of data quality, WB projects were chosen to be the subject of this research project. The initial data load was conducted in September 2012 with documents (type: spreadsheet) pertaining to 49 LDCs respectively. These spreadsheets contain links to around 30,500 documents $^{3}$-about 2,000 of which being ICR documents- of roughly 5,500 projects. To maintain focus on data with required research relevance, this paper only references ICR documents released after the MDGs were officially passed (9/8/2000). ${ }^{4}$ Therefore, this paper is based on researching 790 ICR documents among all of the LDCs (WB (2012)).

\footnotetext{
${ }^{3}$ Author's Note: The roughly 30,500 documents consisted of various document types, such as Project Appraisal, Staff Appraisal, Procurement Program, Project Plan Country Assistance Strategy, Credit Agreement, Environmental Assessment, Sectorial Review (e.g. energy, infrastructure), Annual and Board as well as Social Analysis documents respectively reports.
}

${ }^{4}$ Author's Note: Projects might have been started and closed before that date already. 


\subsubsection{Implementation Completion and Results Reports}

The ICR report is one of the main instruments of self-evaluation and serves as an integral part to increase development effectiveness of the WB. Reports are prepared by the WB at the close of every IDA or IBRD funded operation containing major financial figures. The ICR represents a continuous process of self-evaluation, lessons learned, knowledge sharing and being accountable for results. The following summarizes the main intention of the ICR and its system:

- Provide a complete account of the performance and results of each project and operation.

- Capture and dispose experience from previous projects in order to:

a) improve future interventions to achieve the goals of the Country Assistance Strategy (CAS),

b)improve the design and implementation of up-coming operations through lessons learned, and

c) ensure a greater development impact and sustainability for these future operations.

- Provide accountability and transparency at the project level while considering the bank, borrower and involved stakeholders.

- Provide an instrument for realistic self-evaluation of performance by the bank and borrowers (government and implementation agency).

- Contribute to databases for analysis and reporting, especially by the Quality Assurance Group and the Independent Evaluation Group (IEG) on the effectiveness of development assistance in contributing to development strategies at the various levels (sector, country, and global).

The audience for the ICR is both internal (e.g. board members, bank managers and staff) and external (governments and their agencies, stakeholders, and beneficiaries in partner countries, as well as the general public). In general, the final ICR is publicly disclosed at the time it is submitted within the WB and to the board (WB (2013), p. 3 et seq.; World Press (2006), p. 1 et sqq.).

\subsection{Term "Performance"}

Generally, performance can be defined as the fulfillment of a given task measured against a pre-defined standard of accurateness, cost, and schedule (BusinessDictionary (2015)). However, in this research project performance is referred as the positive or negative outcomes of the researched data set. Hereby several factors need to be considered and answers to the following question will help to formulate a judgment on development aid delivered by the WB and the potential value-add for the developing countries:

- How can the disclosed financial indicators for the WB projects be interpreted and is their outcome positive?

\section{Social Return on Investment}

In the following sections, the SROI concept is explained. Firstly, the proper definition, approach and principles as well as processes of carrying out the SROI analysis is compiled and provided. Finally, the calculation of the SROI value is discussed.

\subsection{SROI Definition}

The SROI is an approach which puts a monetary value on different social investments. The SROI concept was developed by the Roberts Enterprise Development Fund (REDF), a philanthropy organization in California. In general, the approach can be used by a range of different organization types, such as non-profit (or voluntary) and social enterprises across public and private sectors, independent of the company size and maturity. Specifically, non-profit organizations and social enterprises use the SROI as a management tool to improve their performance and outline added value (The SROI Network (2014): The Guide in English 2012 Edition, p. 11 et sqq.).

Using the SROI approach, social, economic and environmental outcomes of a project, organization or policy can be better understood and managed. The objective is to reveal the value of outcomes which does not have direct market values, and thus the approach uses well-founded financial assumptions based on stakeholders' objectives.

There are 2 types of SROIs, the evaluative and the forecast SROI. Evaluative SROIs are based on past outcomes, whereat forecast SROIs predict the social value of the future. The approach is similar to the Return on Investment (ROI) method which businesses use to value return on investments (also known as discounted cash flow method). The ROI approach takes the cash flows which an investment is expected to generate over its lifetime and then "discounts" the value of these future cash flows to today's value (nef - economics as if people and the planet mattered (2011): Social Return on Investment; The SROI Primer (2011): Measuring Social Impact: The Foundation of Social Return on Investment [SROI]; The SROI Network (2014): What is SROI?). 


\subsection{SROI Calculation}

The first step in calculating the SROI ratio requires the projection of all outcomes -based on their persistence- into the future. This sets the basis for calculating the PV and NPV. Based on the outcomes' persistence, the values of their impact are set -normally for 1 time period (usually 1 year). The value for each outcome is then applied across the number of periods it will last, before any drop-offs are subtracted for each of the future periods after the first period. In the second step the NPV needs to be calculated. In order to do so the costs paid and the benefits received in different periods need to be added up. To ensure that the costs and benefits are compared on an equal basis, discounting is used (this is generally referred as "time value of money"). In order to appropriately valuate future cash flows, the determination of the appropriate Rate of Return (RR) is key. Obviously, this is a controversial area with ongoing discussion and research since short-termism is encouraged by discounting the future. The most commonly applied model of the PV can be described as follows (Investopedia (2014): NPV; Projektmagazin (2014); Investopedia (2014): PV; The SROI Network (2014): The Guide in English 2012 Edition, p. 66. et sqq.):

$$
P V=\sum_{t=1}^{n} \frac{\text { Value of } \text { Impact }_{t}}{(1+i)^{t}}
$$

\section{$\underline{\text { where }}$}

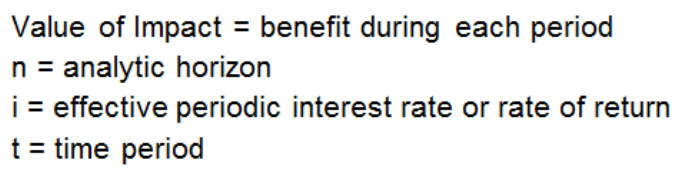

Equation 1. Present Value

(Own illustration, following The SROI Network (2014): The Guide in English 2012 Edition, p. 66. et seq.)

The PV is defined as the current worth of a future sum of money of cash flows given a specified RR. In principle, future cash flows are discounted at a specific RR, whereat the higher the RR, the lower the PV of the future cash flows. The NPV can be defined as the difference between the PV of cash inflows and the PV of cash outflows. The following formula shows the calculation of the NPV. The only difference comparing to the formula of the PV is that instead of the "Value of Impact" the total cash flows (cash in and out) per period are applied to the numerator (Investopedia (2014): NPV; Projektmagazin (2014); Investopedia (2014): PV; The SROI Network (2014): The Guide in English 2012 Edition, p. 66. et sqq.):

$$
N P V=\sum_{t=1}^{n} \frac{\text { Cash Flow }_{t}}{(1+i)^{t}}
$$

\section{where}

Cash Flow = cash flow (cash in and out) during each period (including initial investment in $\mathrm{t}=0$ )

$\mathrm{n}=$ analytic horizon

$i=$ effective periodic interest rate or rate of return

$t=$ time period

Equation 2. Net Present Value

(Own illustration, following The SROI Network (2014): The Guide in English 2012 Edition, p. 66. et seq.)

A NPV greater than 0 indicates the investment as value adding. A NPV less than 0 indicates that the investment would have a negative outcome in terms of adding value for the investors and thus is not recommended. In the case of NPV equal to 0 , the investment provides neither a positive nor a negative value add (Investopedia (2014): NPV; Investopedia (2014): PV; The SROI Network (2014): The Guide in English 2012 Edition, p. 66. et sqq.).

In order to calculate the SROI ratio the discounted value of benefits (PV) needs to be divided by the discounted total respective investment costs:

$$
\text { SROI Ratio }=\frac{P V}{\text { Total Costs }}=\frac{N P V+\text { Total Costs }}{\text { Total Costs }}
$$

Equation 3. Social Return on Investment Ratio

(Own illustration, following The SROI Network (2014): The Guide in English 2012 Edition, p. 68. et seq.)

\subsection{SROI of World Bank Projects}

In the following the relevant indicators for calculating the SROI of the WB projects as well as the calculation of the proper SROI ratio are examined. 


\subsubsection{Indicators of the SROI Calculation}

In this chapter the key indicators and their specifications for calculating the SROI of the WB projects are presented and discussed.

\subsubsection{Net Present Value}

The NPV disclosure within the ICR reports builds the foundation for the proper SROI calculation of the LDCs of this research project. Not only is NPV the central concept of the SROI calculation in general and that it defines if an investment is meaningful or not, it is further the preferred method of project evaluation of the WB. The NPV disclosed within a report is also commonly referred to as the Economic-NPV or E-NPV ${ }^{5}$. A positive NPV contributes to the fundamental objective underlying the WB's policy which is the strengthening of a country's economy, and more generally, the increase in welfare of poorer countries. Thus, a positive effect on a single country's economy has a positive ripple effect on the world's economy itself or -most positively spoken- the country itself does require less or none funds in the future (Pearce/Giles/Susana (2006), p. 70). In principle, there are 2 types of NPVs which can be identified for WB projects:

1. Overall-NPV: The sum of NPVs of each existing project component. Generally, all project costs (all capital/investment and recurring costs) have been considered in order to calculate the overall-NPV. ${ }^{6}$

2. Partial-NPV: The NPV of a project component or of multiple project components, but never refers to all project components. A partial-NPV is only declared in case the ICR document does not disclose an overall-NPV. To calculate a partial-NPV only related project costs (capital and recurring costs) of the corresponding project components haven been considered.

\subsubsection{Capital and Recurring Costs}

In order to calculate SROI based on disclosed NPVs the corresponding cost information needs to be gathered based on the NPV-disclosing ICR document. In principle, there are 2 different types of costs which need to be distinguished:

1. Investment or capital costs: Capital costs are costs of funds used for financing a business (Investopedia (2014): Cost of Capital). Cost of capital depends on the mode of financing used, whereat in the context of development aid funds from the donor countries -or more specific from the WB- it is provided to the government of the fund-receiving country. The agreed funding ${ }^{7}$ is then used to ensure that the project objectives are fulfilled within the foreseen project timeframe. Therefore, capital costs can include expenses on works, goods and equipment, services, consulting, training, resources as well as contingencies. In general, the funding provided does mirror or cover the project required capital costs. Depending on whether it is a partial- or overall-NPV, the costs to be applied may vary. In case of a partial-NPV only related capital costs are considered, whereas in general all capital costs are taken into account for an overall-NPV.

2. Recurring operational and maintenance costs: Regular costs which incur repeatedly or for each item produced or each service performed (Business Dictionary (2014): Recurring Cost). In general, recurring costs are not part of the funding provided to the receiving country and therefore normally provided by the country itself. Examples of recurring operation and maintenance costs include continuous street maintenance and necessary reparations during and after the delivery of an infrastructure project or ongoing energy costs for running a power plant, hospital, or other welfare institutions. Only in few project cases there are no recurring costs existing. The issue with the ICR documents is that in nearly all cases where a NPV value is outlined, there is no detailed calculation available. Further, very often the amount of recurring costs is not even outlined despite

\footnotetext{
${ }^{5}$ Author's Note: Within this research paper the abbreviation "NPV" is used for the E-NPV.

${ }^{6}$ Author's Note: Please refer to the NPV calculation of any country ICR document publicly available under the WB homepage (http://documents.worldbank.org/curated/en/country). However, there are some overall-NPVs where not all invested capital costs of the project have been considered for the NPV calculation.

${ }^{7}$ Author's Note: Only in exceptional cases the funding amount is higher/lower than the capital costs required for the project. In case of a higher funding amount the remaining budget might need to be given back or used to cover some of the recurring costs (case-to-case decision of the WB responsible in charge). In case the funding amount is lower than the capital costs the country itself may have been requested to cover the additional capital expenses.
} 
their existence. ${ }^{8}$ Although recurring costs have already been considered during the NPV calculation they need to be taken into account again in order to establish the project SROI ratio.

To provide a common basis for comparison, both cost types need to be discounted before the SROI ratio calculation (The SROI Network (2014): The Guide in English 2012 Edition, p. 64 et sqq.).

\subsubsection{Calculation of the Proper SROI Ratio}

All of the above described ratios have a common weakness: Due to the fact that the disclosed partial-NPVs only consider corresponding projects costs, each ratio involving partial-NPVs misses the remaining project costs. Therefore, a basis of comparison between ratios based on the total project costs and the partial-NPVs is not warranted. The reasons why often partial-NPVs and no overall-NPVs are disclosed are unknown and not mentioned within the ICR documents, but a timely known and broadly discussed issue.

The focus and goal of this research paper is to calculate a minimum SROI ratio which considers all capital and recurring costs in order to give a clear picture of the cost-benefit relationship of the development assistance provided by the WB. Therefore, the remaining project costs of the partial-NPV projects need to be considered as part of the NPV calculation itself. However, the following challenges need to be considered when trying to manipulate the partial-NPVs disclosed by the ICR department of the WB (Baneth, Jean (1996), p. 28 et sqq.; Pearce/Giles/Susana (2006), p. 86 et seq.; Squire/van der Tak (1975); p. 21 et sqq.):

- Are there benefits related to the remaining project costs from unevaluated project components?

- Besides the remaining capital costs of the project, are there also additional recurring costs for those components which need to be considered?

In order to disclose a minimum SROI for the LDCs, no benefits for the remaining components of all partial-NPV projects will be assumed. This ensures that the calculated SROI ratio is not valued too high due to inaccurate assumptions on potential benefits. The calculation for a minimum SROI will follow a two-step approach, in which adjustment needs to happen on a project level first before the SROI values can be aggregated onto the portfolio level of the LDCs:

1. In the first step the partial-NPV value will be adjusted by applying the discounted remaining capital costs to its calculation. Herewith, all known costs have then been considered.

2. In order to also account for potential recurring costs of the remaining capital costs of the partial-NPVs a standard approach for calculating them will be applied. Those costs will then be applied to the NPV calculation in the first step and be taken into account when calculating the minimum SROI ratio.

\section{Outcomes of the NPV and SROI Analysis}

In this chapter the analysis approach and setup taken for this research project are presented, before the overall results of the NPV calculation of the LDCs are outlined. The subsequent chapter deals with the calculation principle of the minimum SROI ratio. Afterwards the results of the minimum SROI calculation of the LDCs are examined and discussed. The last sub-chapter deals with additional aspects and calculations in order to make meaning out of the presented results.

\subsection{Analysis Approach and Setup}

Based on the initial data load conducted in September of 2012, 790 ICR documents serve as the data source for the NPV analysis. Data available within these documents are regarded as raw data. In order to be able to access and analyze the economic and financial indicators as provided in ICR documents, each ICR had to be examined by browsing through relevant sections to locate specific financial key words and abbreviations of them. This ensures that no relevant details get missed and that the different naming conventions and expressions used in the ICR documents are covered. The ICR documents vary in size from 9 to 154 pages. The average document size is 53 pages. With a total of 790 ICR documents, it amounts to more than 42,000 pages.

\subsection{Overall Results of the NPV Outcomes of the LDCs}

In this chapter the NPVs of the result stage of an ICR document and their corresponding values for the LDCs as a whole are presented.

In total, $168 \mathrm{NPVs}$ based on results calculations are disclosed which represents a disclosure rate of about 21.3 percent.

\footnotetext{
${ }^{8}$ Author's Note: For projects not outlining existing recurring costs a standard approach for calculating them based on the LDC specific recurring costs coefficients needs to be undertaken. This concept will be explained in chapter 4.3 Calculation Principle of the Minimum SROI Ratio.
} 
In total there are 60 overall- and 108 partial-NPVs.

The following table shows outcomes of the economic analysis of the result NPV and cost values based on the cumulative sum and the arithmetic mean:

The cumulative sum of the minimum NPV result values from the 168 ICR reports is approx. 42,059 Mio USD at minimum and could increase to more than 50,000 Mio USD based on the maximum values disclosed. ${ }^{9}$ The average NPV value per project ranges between 250 and 302 Mio USD. Therefore, it can be concluded that the NPV disclosing projects are generally profitable. These values are based on an average 11.2 percent discount rate, 7 years project duration, and an average 19 years NPV-horizon ${ }^{10}$. The cumulative sum of the NPVs is approx. 80 percent higher than the related capital costs in the minimum case and 115 percent higher in the maximum case. Consequently, it can be concluded that the result NPV disclosing projects generate values twice as much as their corresponding NPV capital costs. There are no noteworthy differences found between the minimum and maximum cumulative sum of the NPV related capital costs. The difference of approx. 8,000 Mio USD between the minimum and maximum cumulative sum of the total NPVs is due to the difference between the minimum and the maximum cumulative sum of the overall-NPVs ${ }^{11}$ (approx. 6,779 Mio USD vs. 14,391 Mio USD). In the case of minimum cumulative sum of the overall-NPVs, it is less than half of the cumulative sum of the related capital costs and also lower than the related capital costs in the case of maximum sum. Another point to mention is that the cumulative maximum amount of the capital costs of the overall-NPVs is lower than the cumulative minimum amount. Here the reason lies in a project neutral NPV calculation, since for the negative minimum overall-NPV calculation all project costs but for the positive maximum overall-NPV only specific project costs have been considered. Taking a closer look at the partial-NPVs it can be noticed that those are the ones making up more than 80 percent of the total cumulative minimum NPV sum and even more than 70 percent of the total cumulative maximum NPV sum. The related capital costs only account for a share of approx. 22 percent of the cumulative sum of the NPV. The partial-NPV capital costs are in general only half as high as the overall-NPV capital costs, whereat the total project costs of the partial-NPV projects actually exceed the ones of the overall-NPV projects by roughly 2,000 Mio USD. The fact that the partial-NPV related total project costs are actually 2.3 times higher than the related capital costs is not surprising, since it lies in the nature of a partial-NPV and hence only NPV related components and costs is considered. ${ }^{12}$

\footnotetext{
${ }^{9}$ Author's Note: The "minimum"/"maximum" case is based on the minimum/maximum NPVs, resulting from the existence of a minimum and a maximum NPV value outlined within multiple ICR documents. The same applies to the outlined capital costs.

${ }^{10}$ Author's Note: NPV-horizon is defined as the time period which is used in order to discount the recurring costs. It is generally referred to as the total lifespan of the respective project during which the whole costs occur and benefits should be generated. A NPV-horizon begins with the project start period.

${ }^{11}$ Author's Note: Taking a closer look at the costs of the overall-NPV projects there is a slight difference of the overall-NPV related capital costs which are in this case a bit lower than the total project costs. This discrepancy is due to the fact that there are projects where funding is used for operational and maintenance works or mismatches between the outlined total project costs in the Appendices of the ICR documents and the costs disclosed in the detailed NPV calculation tables (if available).

${ }^{12}$ Author's Note: Another point to mention is that the WB financing only makes up about 27 percent of the total project costs. Therefore, it can be concluded that also for the result values the disclosed sector codes of the WB financing of a project are not representative for the project type as a whole.
} 
Table 1. Result NPV and Cost Values of the LDCs

\begin{tabular}{|c|c|c|c|c|c|c|c|}
\hline \multirow{2}{*}{\multicolumn{2}{|c|}{ Values in Mio USD }} & \multicolumn{6}{|c|}{ LDCs } \\
\hline & & \multicolumn{2}{|c|}{ Total NPVs (168) } & \multicolumn{2}{|c|}{ Overall-NPVs (60) } & \multicolumn{2}{|c|}{ Partial-NPVs (108) } \\
\hline & & Cum Sum & $\varnothing$ & Cum Sum & $\varnothing$ & Cum Sum & $\varnothing$ \\
\hline \multirow{2}{*}{ NPV } & Minimum & 42,059 & 250 & 6,779 & 113 & 35,280 & 327 \\
\hline & Maximum & 50,779 & 302 & 14,931 & 249 & 35,847 & 332 \\
\hline \multirow{2}{*}{$\begin{array}{l}\text { Total NPV Capital } \\
\text { Costs (actual) }\end{array}$} & Minimum & 23,408 & 139 & 15,648 & 261 & 7,760 & 72 \\
\hline & Maximum & 23,578 & 140 & 15,641 & 261 & 7,937 & 73 \\
\hline \multicolumn{2}{|c|}{ Total Project Costs (actual) } & 33,506 & 199 & 15,810 & 263 & 17,696 & 164 \\
\hline \multicolumn{2}{|c|}{ Total World Bank Costs (actual) } & 9,110 & 54 & 2,582 & 43 & 6,528 & 60 \\
\hline \multicolumn{2}{|c|}{ Discount Rate [\%] } & \multicolumn{2}{|c|}{11.21} & \multicolumn{2}{|c|}{11.39} & \multicolumn{2}{|c|}{11.11} \\
\hline \multicolumn{2}{|c|}{ Actual Project Duration [years] } & \multicolumn{2}{|c|}{7.02} & \multicolumn{2}{|c|}{7.1} & \multicolumn{2}{|c|}{6.98} \\
\hline \multicolumn{2}{|c|}{ NPV-horizon [years] } & \multicolumn{2}{|c|}{19.33} & \multicolumn{2}{|c|}{18.15} & \multicolumn{2}{|c|}{19.95} \\
\hline
\end{tabular}

Furthermore, it should be noted that there are 7 out of the 168 result NPV projects which disclose NPV values within the 1- to 2-digit billion range. In comparison, the NPV values of the remaining 161 result NPV projects are located in the 2- to 3-digit Mio range. ${ }^{13}$ The "Third Road Rehabilitation and Maintenance Project (RRMP III)" is the project outlining the highest result NPV value of 11,179 Mio USD at the appraisal stage. The following table shows the outcome, when all "high-value" NPV projects data are excluded:

Table 2. Result NPV and Cost Values of the LDCs excluding "high-value" NPVs

\begin{tabular}{|c|c|c|c|c|c|c|c|}
\hline \multirow{3}{*}{\multicolumn{2}{|c|}{ Values in Mio USD }} & \multicolumn{6}{|c|}{ LDCs } \\
\hline & & \multicolumn{2}{|c|}{ Total NPVs } & \multicolumn{2}{|c|}{ Overall-NPVs } & \multicolumn{2}{|c|}{ Partial-NPVs } \\
\hline & & Cum Sum & $\varnothing$ & Cum Sum & $\varnothing$ & Cum Sum & $\varnothing$ \\
\hline \multirow{2}{*}{ NPV } & Minimum & 6,188 & 38 & 2,226 & 57 & 3,961 & 38 \\
\hline & Maximum & 7,799 & 48 & 3,270 & 58 & 4,529 & 43 \\
\hline \multirow{2}{*}{$\begin{array}{l}\text { Total NPV Capital } \\
\text { Costs (actual) }\end{array}$} & Minimum & 10,458 & 65 & 3,506 & 63 & 6,952 & 66 \\
\hline & Maximum & 10,627 & 66 & 3,499 & 62 & 7,129 & 68 \\
\hline \multicolumn{2}{|c|}{ Total Project Costs (actual) } & 20,280 & 126 & 3,668 & 65 & 16,612 & 158 \\
\hline \multicolumn{2}{|c|}{ Total World Bank Costs (actual) } & 7,845 & 49 & 1,934 & 35 & 5,911 & 56 \\
\hline \multicolumn{2}{|c|}{ Discount Rate [\%] } & \multicolumn{2}{|c|}{11.2} & \multicolumn{2}{|c|}{11.42} & \multicolumn{2}{|c|}{11.08} \\
\hline \multicolumn{2}{|c|}{ Actual Project Duration [years] } & \multicolumn{2}{|c|}{7} & \multicolumn{2}{|c|}{7.04} & \multicolumn{2}{|c|}{6.98} \\
\hline \multicolumn{2}{|c|}{ NPV-horizon [years] } & \multicolumn{2}{|c|}{19.74} & \multicolumn{2}{|c|}{18.94} & \multicolumn{2}{|c|}{20.13} \\
\hline
\end{tabular}

Excluding the 7 "high-value" NPV projects results in a fully reduced and "slimmed" values picture. The resulting NPV now only lies at between 6,188 and 7,799 Mio USD which is only about 15 percent of the NPV of the total LDCs. Therefore, the resulting arithmetic mean of the NPVs as well drops to less than a sixth of the original value. In contrast, the NPV related capital costs decrease as well, but only by a little over 50 percent to 10,458 respectively 10,627 Mio USD. There are no noteworthy changes to the average values of the discount rate, actual project duration or to the NPV-horizon. The notable difference between the NPV and cost values of the overall- and the partial-NPVs diminishes as well. Still, the partial-NPVs disclose higher NPV values compared with the overall-NPVs. Taking a closer look by comparing the overall- vs. the partial-NPVs, the NPV/capital cost ratio of the overall-NPVs $(0.63$ in the minimum and 0.93 in the maximum case) is better than the one of the partial-NPVs ( 0.57 in the minimum and 0.64 in the maximum case). This difference between the overall- and partial-NPV/capital cost ratios would even be more significant where all project related capital costs have been taken into account for the partial-NPV projects.

To follow up on this analysis a general question to be answered is 'how positive are the NPV projects at all?' In order to

\footnotetext{
${ }^{13}$ Author's Note: The NPV values of the remainder of the 161 projects do have a range from -13.451.752 USD till 423 Mio USD with an average arithmetic mean of 38.431.762 Mio USD in the minimum and 48.440.645 Mio USD in the maximum case.
} 
find out if the total of partial- and overall-NPV disclosing projects are positive, the following chapters aim to discuss and calculate a minimum SROI for the LDCs.

\subsection{Calculation Principle of the Minimum SROI Ratio}

This chapter aims to calculate a minimum SROI ratio for the LDCs. As described in chapter 3.2.2 Calculation of the proper SROI Ratio the calculation of the minimum SROI ratio follows a two-step approach.

In the first approximation the remaining capital costs are distributed and discounted evenly across the corresponding project lifetime period and subsequently deducted from the corresponding partial-NPV value.

In the second step, standardized recurring costs based on the remaining capital costs of the partial-NPVs are additionally considered. In order to calculate the amount of the recurring costs for partial-NPV projects the already presented varying LDC and continent specific recurring costs coefficients are used. Once calculated, the standardized recurring costs are again distributed and discounted evenly across the project specific NPV-horizon. Thereafter, the discounted project recurring costs will be deducted from the corresponding NPV together with the discounted remaining capital costs calculated in the first step. Additionally, those costs need to be added to the total costs of the minimum SROI ratio. The formula below visualizes this calculation:

$$
\text { Minimum SROI Ratio }=\frac{(N P V-C-R)+(C R i+C+R)}{(C R i+C+R)}=\frac{N P V+C R i}{C R i+C+R}
$$

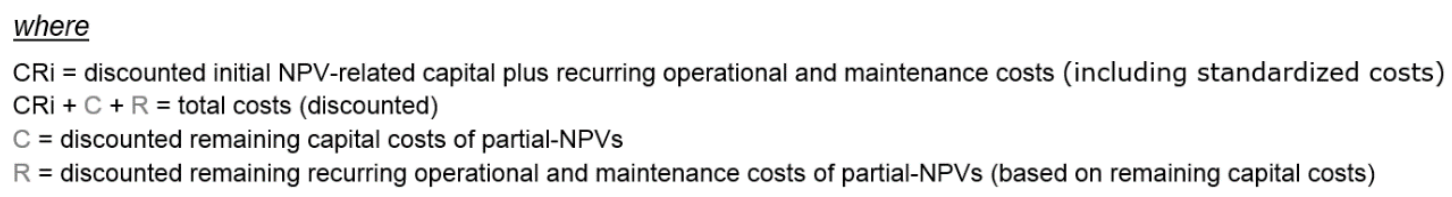

Equation 4. Minimum SROI Ratio

The portfolio minimum SROI ratio is calculated using the specific weighted and unweighted recurring costs coefficients of the LDCs.

The recurring costs coefficient describes the multiplier for the capital costs of a project in order to derive the project recurring costs. The weighted recurring costs coefficient is the quotient of the sum of all available recurring costs divided by the sum of the related capital costs. The unweighted recurring costs coefficient is the arithmetic mean of all available project recurring costs coefficients. A project recurring costs coefficient is the quotient of the recurring project costs divided by the corresponding capital costs. In order to account for exceptionally high project recurring costs coefficients, different versions of the unweighted recurring costs coefficient will be used.

The portfolio disclosure of the SROI ratios is again based on the minimum and maximum values of the weighted and unweighted arithmetic means. It needs to be noted that the adjustment of the NPV values based on an even distribution and discounting of costs is key.

\subsection{Overall Results of the Minimum SROI Ratio of the LDCs}

This chapter presents the results of the minimum SROI ratio of the LDCs. The 168 NPV projects again served as a basis. In order to calculate the additional recurring costs, respective LDC continent specific recurring costs coefficients of Africa and Asia were used. ${ }^{14}$ Once the additional recurring costs were calculated they were distributed and discounted evenly across the corresponding NPV-horizon using standard NPV-horizons and discount rates where necessary. The table below shows the results of the minimum SROI ratio of the LDCs based on different recurring costs coefficients:

\footnotetext{
${ }^{14}$ Author's Note: For all of the 108 partial-NPV projects the remaining capital costs needed to be calculated based on the respective LDC continent specific recurring costs coefficients.
} 
Table 3. Minimum SROI Ratio of the $\mathrm{LDCs}^{15}$

\section{LDCs}

\begin{tabular}{|c|c|c|c|c|}
\hline $\begin{array}{c}\text { Reuring }^{\text {Costs }} \\
\text { Coefficient }\end{array}$ & \multicolumn{2}{|c|}{$\varnothing$ - weighted } & \multicolumn{2}{c|}{$\varnothing$ - unweighted } \\
\hline $\mathbf{0 . 6 2}$ & 1.92 & 2.19 & 2.11 & 2.88 \\
\hline $\mathbf{1 . 3 4}$ & 1.68 & 1.91 & 1.8 & 2.45 \\
\hline $\mathbf{3 . 6}$ & 1.25 & 1.41 & 1.38 & 1.87 \\
\hline $\mathbf{1 3 . 2 9}$ & 0.74 & 0.82 & 0.98 & 1.25 \\
\hline
\end{tabular}

Generally, the outcome of the minimum SROI ratio of all 168 discovered NPVs can be regarded as positive. Even for the weighted recurring costs coefficient of 3.6 the result ratios are positive with a ratio of 1.25 and 1.41 for the weighted minimum and maximum ratios and 1.38 and 1.87 for the unweighted minimum and maximum ratios. Only when applying the initial and unadjusted unweighted recurring costs coefficient of 13.29 the weighted ratio outcomes are both negative, whereas the unweighted ratios still yield positive results with 0.98 in the minimum and 1.25 in the maximum case.

In order to account for the "high-value" bolters, the data set is cleaned up by excluding the 10 projects again. The table below shows the outcome of the minimum SROI ratio for varying recurring costs coefficients:

Table 4. Minimum SROI Ratio of the LDCs excluding "high-value" Projects ${ }^{16}$

\section{LDCs}
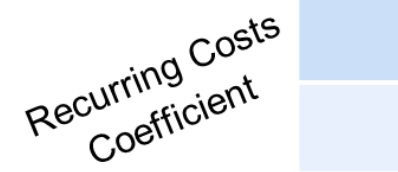

\section{$\varnothing$ - weighted}

$\varnothing$ - unweighted

\begin{tabular}{|c|c|c|c|c|}
\hline $\mathbf{0 . 6 2}$ & 1.01 & 1.12 & 1.66 & 2.16 \\
\hline $\mathbf{1 . 1 7}$ & 0.94 & 1.03 & 1.5 & 1.96 \\
\hline $\mathbf{2 . 6 4}$ & 0.82 & 0.89 & 1.27 & 1.68 \\
\hline $\mathbf{1 2 . 9 9}$ & 0.62 & 0.66 & 0.91 & 1.15 \\
\hline
\end{tabular}

The unweighted ratios remain positive even for the weighted recurring costs coefficient of 2.64. Only when applying the initial and unadjusted unweighted recurring costs coefficient of 12.99 the minimum value falls to 0.91 , whilst the maximum ratio remains at 1.15 . The weighted ratios are only positive for the fully embellished unweighted recurring costs coefficient of 0.62 . For the adjusted unweighted recurring costs coefficient of 1.17 the minimum value is already down at 0.94 , whereas the maximum one still stays positive with a ratio of 1.03 . Obviously, the weighted minimum SROI ratios decreases further as the applied recurring costs coefficient increases.

\footnotetext{
${ }^{15}$ Author's Note: $0.62,1.34,13.29$ are unweighted recurring costs coefficients. The calculation of those coefficients is based on the exclusion of different bolter recurring costs coefficient groups.

${ }^{16}$ Author's Note: $0.62,1.17,12.99$ are unweighted recurring costs coefficients. The calculation of those coefficients is based on the exclusion of different bolter recurring costs coefficient groups.
} 


\subsection{Making Meaning of the Results}

This chapter deals with the outcome analysis of the minimum SROI of the LDCs. As discussed in the previous chapter the weighted minimum ratio of the LDCs was already below 1 for a recurring costs coefficient of 1.17. Therefore, the idea is to define the most realistic recurring costs coefficient for the LDCs. In order to do so, specifically those projects which outlined the highest recurring costs coefficients were analyzed further. In a second step the projects which were responsible for decreasing the weighted arithmetic means of the minimum SROI of the LDCs were further analyzed and discussed.

The question to be answered in the first step was, 'which projects actually drive the recurring costs coefficient up and what kind of projects are these?'

Analyzing the recurring costs coefficients of the 5 LDC projects with very high recurring costs coefficients helped to address this question. The following table provides an overview of those projects and the respective recurring costs coefficient:

Table 5. "High-value" Recurring Costs Coefficients of the LDCs

\section{High-Value Recurring Costs Coefficients}

\begin{tabular}{|c|c|c|c|}
\hline Continent & Country & Report & $\begin{array}{c}\text { Recurring Costs } \\
\text { Coefficient }\end{array}$ \\
\hline Africa & Benin & 21512 & 33 \\
\hline Africa & Chad & ICR1891 & 27 \\
Asia & Cambodia & 22038 & 19 \\
\hline Asia & Samoa & ICR1793 & 132 \\
Asia & Yemen & 27440 & 214 \\
\hline
\end{tabular}

The highest recurring costs coefficients range from 19 to 214, with 3 of them belonging to the Asian continent. In the case where those 5 coefficients are excluded when calculating the average unweighted recurring costs coefficient of the LDC data set (excluding the 10 "high-value" projects) the coefficient comes down from 12.99 to $2.4{ }^{17}$ In order to understand what kind of projects the "high-value" recurring costs coefficient projects are, the following table provides an overview of their NPV and costs values:

Table 6. NPV and Cost Values of the "high-value" Recurring Costs Coefficient Projects

\begin{tabular}{|c|c|c|c|}
\hline \multirow{2}{*}{\multicolumn{2}{|c|}{ Values in Mio USD }} & \multicolumn{2}{|c|}{$\begin{array}{l}5 \text { High Recurring Costs } \\
\text { Coefficient Projects }\end{array}$} \\
\hline & & Cum Sum & $\varnothing$ \\
\hline \multirow{2}{*}{ NPV } & Minimum & 42 & 8 \\
\hline & Maximum & 56 & 11 \\
\hline \multirow{2}{*}{$\underset{\text { (Coefficient 2.64) }}{\text { Minimum NPV }}$} & Minimum & -122 & -24 \\
\hline & Maximum & -108 & -22 \\
\hline \multirow{2}{*}{$\begin{array}{l}\text { Total NPV Capital } \\
\text { Costs }\end{array}$} & Minimum & 69 & 14 \\
\hline & Maximum & 69 & 14 \\
\hline \multicolumn{2}{|c|}{ Total Project Costs } & 150 & 30 \\
\hline \multicolumn{2}{|c|}{ Total World Bank Costs } & 132 & 26 \\
\hline \multicolumn{2}{|c|}{ Discount Rate [\%] } & \multicolumn{2}{|c|}{10.9} \\
\hline \multicolumn{2}{|c|}{ Project Duration [years] } & \multicolumn{2}{|c|}{7} \\
\hline \multicolumn{2}{|c|}{ NPV-horizon [years] } & \multicolumn{2}{|c|}{27} \\
\hline
\end{tabular}

\footnotetext{
${ }^{17}$ Author's Note: The exclusion of the 5 "high-value" recurring costs coefficients brings the coefficient of the complete dataset of the $168 \mathrm{NPV}$ projects of 13.29 down to 2.52 .
} 
Comparing the average NPV and cost values with the ones of the LDCs excluding the "high-value" NPVs there are multiple and relevant differences (chapter 4.2 Overall Results of the NPV Outcomes of the LDCs, table 2: Result NPV and Cost Values of the LDCs excluding "high-value" NPVs):

- The average NPVs of 8 and 11 Mio USD are far below the ones of the LDCs excluding "high-value" NPVs of 38 and 48 Mio USD.

- After adjustment of partial-NPVs via the corresponding project remaining capital and recurring costs the average NPVs come down to -24 and -22 Mio USD using the weighted recurring costs coefficient of 2.64 of the LDCs excluding "high-value" projects.

- The average NPV capital costs of 14 Mio USD is well below the ones of the LDCs excluding "high-value" NPV projects of 65 and 66 Mio USD.

- The average total project costs of 30 Mio USD is well below the ones of the LDCs excluding "high-value" NPV projects of 126 Mio USD.

- The share of the WB costs of the total project costs is approx. 87 percent and thus a lot higher than the one of the LDCs excluding "high-value" NPV projects of 39 percent (49 out of 126 Mio USD).

- Considering the outcome of the sector types of the WB funds, it can be noted that 50 out of the 132 Mio USD belong to the 'Distribution and Transmission' sector code ${ }^{18}$. This amount actually mirrors the total amount for this sector code for the whole of the WB funds of the whole LDCs.

- The average NPV-horizon of 27 years is much higher than the 19.74 years of the LDCs excluding "high-value" NPVs.

In summary, the "high-value" recurring costs coefficient projects are characterized by low NPV, low NPV related capital, and low total project costs projects. Furthermore, the WB funded amount of the total project costs is unusually high, particularly for the 'Distribution and Transmission' sector code. Therefore, the exclusion of the 5 "high-value" recurring costs coefficients from the remaining coefficient of the LDCs, together with the exclusion of "high-value" projects is reasonable and moreover justifiable.

In the second step, the calculated minimum NPVs of the adjustment via the project specific remaining capital and the corresponding recurring costs were analyzed further. In summary, of the 158 projects which initially contained 7 neutral as well as 7 negative NPV projects, the number of negative NPV projects drastically increased to 76 . In total the numerical count of the neutral project remained at 7 . This basically means that around half of the projects of -and due to- the minimum SROI calculation are based on SROI ratios of less than 1. In order to understand which kind of projects are the negative SROI drivers, 10 projects with calculated minimum NPVs of less than -200 Mio USD were identified. The following table provides an overview of the 10 highest negative calculated minimum NPV projects:

${ }_{18}$ Author's Note: The classification of project types is based and defined as "Sector and Theme Codes" within the ICR documents. Each project can consist of multiple "sector codes" (up to 5 in total) that determine the project type for the project funding provided by the WB. 
Table 7. NPV and Cost Values of the 10 highest negative calculated Minimum NPV Projects

\begin{tabular}{|c|c|c|c|c|c|c|}
\hline \multirow{2}{*}{\multicolumn{2}{|c|}{ Values in Mio USD }} & \multicolumn{2}{|c|}{$\begin{array}{l}10 \text { highest negative } \\
\text { calculated Minimum NPVs }\end{array}$} & \multicolumn{3}{|c|}{ Detailed Project Information } \\
\hline & & Cum Sum & $\varnothing$ & Continent & Country & Report \\
\hline \multirow{2}{*}{ NPV } & Minimum & 477 & 48 & \multirow{11}{*}{$\begin{array}{l}\text { Africa } \\
\text { Africa } \\
\text { Africa } \\
\text { Africa } \\
\text { Africa } \\
\text { Africa } \\
\text { Africa } \\
\text { Africa } \\
\text { Africa } \\
\text { Asia }\end{array}$} & \multirow{11}{*}{$\begin{array}{c}\text { Ethiopia } \\
\text { Mali } \\
\text { Mali } \\
\text { Mozambique } \\
\text { Mozambique } \\
\text { Senegal } \\
\text { Senegal } \\
\text { Tanzania } \\
\text { Zambia } \\
\text { Afghanistan }\end{array}$} & \multirow{11}{*}{$\begin{array}{c}\text { ICR350 } \\
34791 \\
32130 \\
\text { ICR586 } \\
27511 \\
\text { ICR699 } \\
32408 \\
26745 \\
32521 \\
\text { ICR524 }\end{array}$} \\
\hline & Maximum & 756 & 76 & & & \\
\hline \multirow{2}{*}{$\underset{\text { (Coefficient 2.64) }}{\text { Minimum NPV }}$} & Minimum & $-5,566$ & -557 & & & \\
\hline & Maximum & $-4,756$ & -476 & & & \\
\hline \multirow{2}{*}{$\begin{array}{l}\text { Total NPV Capital } \\
\text { Costs }\end{array}$} & Minimum & 1,249 & 125 & & & \\
\hline & Maximum & 1,410 & 141 & & & \\
\hline \multicolumn{2}{|c|}{ Total Project Costs } & 4,541 & 454 & & & \\
\hline \multicolumn{2}{|c|}{ Total World Bank Costs } & 1,308 & 131 & & & \\
\hline \multicolumn{2}{|c|}{ Discount Rate [\%] } & \multicolumn{2}{|c|}{11.3} & & & \\
\hline \multicolumn{2}{|c|}{ Project Duration [years] } & \multicolumn{2}{|c|}{7} & & & \\
\hline \multicolumn{2}{|c|}{ NPV-horizon [years] } & \multicolumn{2}{|c|}{20.27} & & & \\
\hline
\end{tabular}

Again there are some differences worth highlighting when comparing the average NPV and cost values with the ones of the LDCs where the "high-value" NPVs were excluded:

- The average NPVs before the adjustment of 48 and 76 Mio USD are slightly higher than the ones of the LDCs excluding "high-value" NPVs of 38 and 48 Mio USD.

- After adjustment of partial-NPVs via the corresponding project remaining capital and recurring costs, the average NPVs come down to -557 and -476 Mio USD using the weighted recurring costs coefficient of 2.64 of the LDCs excluding "high-value" projects.

- The average NPV capital costs of 125 and 141 Mio USD are twice as high as the ones of the LDCs excluding "high-value" NPV projects of 65 and 66 Mio USD.

- The average total project costs of 454 Mio USD are about 3.5 times higher than the ones of the LDCs excluding "high-value" NPV projects of 126 Mio USD.

- The share of the WB costs of the total project costs of 29 percent is 10 percent lower than the one of the LDCs excluding "high-value" NPV projects of 39 percent (49 out of 126 Mio USD).

What can be noted is the fact that the 10 projects outlining the most negative NPVs are projects with NPVs which are slightly higher than the average NPV of the LDCs excluding "high-value" NPVs, but feature high NPV related capital costs and even higher total project costs. In cases where these projects are excluded from the data set of the 158 NPV projects, the weighted recurring costs coefficient of the remaining 148 projects actually increases from 2.64 to 3 . When calculating the minimum SROI ratio for the 148 projects of the LDCs, the results are as follows:

Table 8. Minimum SROI Ratio of the Remainder of the 148 LDC Projects

\section{LDC Projects}

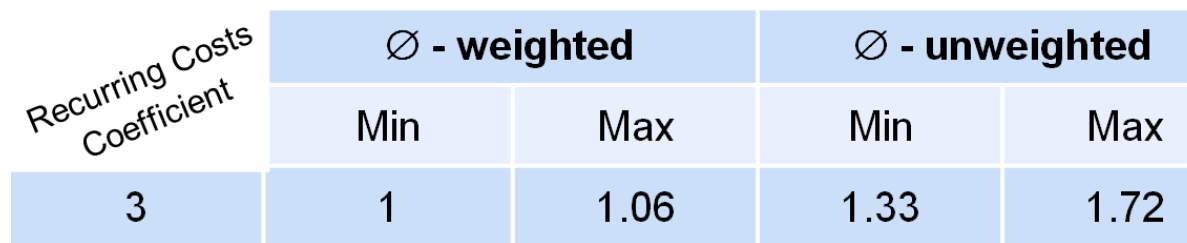

The outcome is simple to interpret. Even in the minimum case of the weighted arithmetic mean, the ratio is slightly above 1 (when rounded to the nearest whole number). The weighted maximum ratio of 1.06 shows a possible monetary value creation of 6 percent for the total of 148 projects. Furthermore, the unweighted ratios show that the average project generates a 1.3 to 1.72 times higher output compared to the given input.

In order to understand what kind of projects actually outline minimum SROIs which are at least as high as the unweighted minimum arithmetic mean of 1.3 , the following table provides an overview of their NPV and cost values: 
Table 9. Projects with Minimum SROIs greater than or equal to 1.3

\begin{tabular}{|c|c|c|c|}
\hline \multirow{2}{*}{\multicolumn{2}{|c|}{ Values in Mio USD }} & \multicolumn{2}{|c|}{ Projects with Minimum SROls $\geq 1.3$} \\
\hline & & Cum Sum & $\varnothing$ \\
\hline \multirow{2}{*}{ NPV } & Minimum & 3,132 & 104 \\
\hline & Maximum & 3,354 & 112 \\
\hline \multirow{2}{*}{$\begin{array}{c}\text { Total NPV Capital } \\
\text { Costs }\end{array}$} & Minimum & 1,213 & 40 \\
\hline & Maximum & 1,213 & 40 \\
\hline \multicolumn{2}{|c|}{ Total Project Costs } & 1,261 & 42 \\
\hline \multicolumn{2}{|c|}{ Total World Bank Costs } & 846 & 28 \\
\hline \multicolumn{2}{|c|}{ Discount Rate [\%] } & \multicolumn{2}{|c|}{11.27} \\
\hline \multicolumn{2}{|c|}{ Project Duration [years] } & \multicolumn{2}{|c|}{6.4} \\
\hline \multicolumn{2}{|c|}{ NPV-horizon [years] } & \multicolumn{2}{|c|}{19.7} \\
\hline
\end{tabular}

When analyzing these projects in detail, it needs to be noted that 16 out of 30 are partial-NPV based. Each project at minimum discloses a SROI ratio of 1.3. The following major differences are noted when comparing the average NPV and cost values of the minimum SROI projects with the ones of the LDCs excluding the "high-value" NPVs:

- The average NPVs of 104 and 112 Mio USD are between 2.3 and 2.7 times higher than the ones of the LDCs excluding "high-value" NPVs of 38 and 48 Mio USD.

- The average NPV capital costs of 40 Mio USD only make up about 60 percent of the ones of the LDCs excluding "high-value" NPV projects of 65 and 66 Mio USD.

- The average total project costs of 42 Mio USD are similarly high as the NPV related capital costs which basically means that the amount of remaining capital costs of the partial-NPVs is negligible.

- The share of the WB costs of the total project costs of 67 percent is about 1.7 times higher than the one of the LDCs excluding "high-value" NPV projects of 39 percent.

- Looking at the outcome of the sector types of the WB funds, 'Roads and highways', 'Power', 'Central government administration' and 'Water supply' still remain the core sector codes as per the whole of the LDCs. However, differences can be found in the 'Power' sector code which shows the second largest \%-share but the highest WB costs with 189 Mio USD out of 846 Mio USD (22.34 percent) compared to the LDCs excluding "high-value" NPV projects where the 'Power' sector code only makes up 783 Mio USD out of 7,845 Mio USD (10 percent). On the other hand the 'Roads and highways' sector code only makes up 16.55 percent compared to 29.75 percent of the LDCs excluding "high-value" NPVs.

Summarizing the outcomes above, it can be noted that projects with high minimum SROIs are not necessarily overall-NPV projects, but at least partial-NPVs with negligible remaining capital costs. Furthermore, these projects disclose around 2.5 times higher NPVs and 40 percent lower NPV related capital costs than the average project of the LDCs excluding "high-value" NPV projects. Last but not least, the share of the WB costs of the total project costs is comparably high, particularly in the 'Power' sector and less in the 'Roads and highways' sector.

Furthermore, the positive overall outcome of the weighted minimum SROI ratio is driven by the still higher Asian weighted ratios. In case the recalculated unweighted recurring costs coefficient of 2.4 was used, the weighted ratios of the 148 LDC projects would increase further. Nonetheless, the most interesting find is the fact that even in the worst case scenario by calculating the minimum SROI ratio of the LDCs and under consideration of the above mentioned restrictions, the outcome for the WB projects is positive the minimum SROI ratios.

\section{Overall Summary and Conclusion}

This paper focused on the evaluation of the WB performance in delivering development aid to the LDCs. After a short introduction to the topic the research approach, the paper's objective as well as the structure were discussed. The third chapter discussed the theory as well as the SROI concept within the context of the ICR documents of the WB.

In the fourth chapter the analyses of the NPV and the calculation of the minimum SROI was conducted. The analyses of the 168 result NPVs of the LDCs showed NPV values of 42,059 to 50,779 Mio USD (33,506 Mio USD of total project 
costs) and 6,188 to 7,799 Mio USD (20,280 Mio USD of total project costs) with 7 "high-value" NPV projects being excluded.

Calculating the theoretic minimum SROI disclosed positive results for all 168 projects: Except when using the initial unadjusted, unweighted recurring costs indicator of 13.29, the weighted ratios were below 1 with arithmetic means of 0.74 in the minimum and 0.82 in the maximum case, whereat the unweighted SROI ratio lay between 0.98 and 1.25. Excluding the "high-value" projects positive results were only displayed for the fully embellished recurring costs coefficient of 0.62 . For the adjusted recurring costs coefficient of 1.17 the weighted minimum ratio was already at 0.94 . Using the weighted recurring costs coefficient of 2.64 only the unweighted ratio stayed positive, whereas both weighted ratios lowered to 0.82 and 0.89 .

In the first step of the final chapter projects responsible for "high-value" recurring costs coefficients were identified. Excluding those projects caused the unweighted recurring costs coefficient to drop from 12.99 to 2.4 for the LDC "high-value" embellished data set. In the second step 10 projects with calculated minimum NPVs of less than -200 Mio USD with high total project costs were identified and excluded from the data set. The remaining 148 projects disclosed positive weighted and unweighted capital SROI ratios based on the weighted recurring costs coefficient of 3 corresponding to the data set. Furthermore, the minimum SROI ratio disclosed values of 1 and 1.06 in the weighted and the 1.3 and 1.72 in the unweighted case. In the last step projects disclosing the highest minimum SROIs were further analyzed. Those were projects with about 2.5 times above the average NPVs of 104 and 112 Mio USD and lower NPV related capital and total project costs of 40 and 42 Mio USD as well as a specific focus on the 'Power' sector code.

As a result from the performed economic and financial analysis, it can be concluded the outcome of the theoretic calculated minimum SROI does signal a positive effect on the LDCs. For both types of the ratio -weighted and unweighted-the outcomes were all above 1 , with a minimum weighted ratio of 1 (rounded down). This means that the WB delivers development aid projects successfully and in general increases the welfare of the recipient country.

In order to follow up on this research and to understand the underlying drivers for high/low NPVs as well as continental differences further analyses comparing the African and Asian continents should be conducted.

\section{References}

Book Literature, Articles and Presentations

Ahrens, H. (2005). Development Cooperation-Evaluation and New Approaches. Schriften des Vereins für Sozialpolitik, Band 308. Duncker and Humblot GmbH, Berlin (Germany) 2005. ISBN 3-428-11867-7. https://doi.org/10.3790/978-3-428-51867-8

Baneth, J. (1996). Selecting Development Projects for the World Bank. In: World Bank Discussion Papers (322), Washington, D. C. 20433 (USA) 1996. ISBN 0-8213-3625-8. https://doi.org/10.1596/0-8213-3625-8

Easterly, W. (2006). The White Man's Burden - Why the West's Efforts to Aid the Rest have done so much Ill and so little Good. Oxford University Press Inc., New York (USA) 2006. ISBN 978-0-19-922611-5.

Köhler, G., Gore, C., Reich, U. P., \& Ziesemer, T. (1996). Questioning Development - Essays in the theory, policies and practice of development interventions. Metropolis-Verlag, Marburg (Germany) 1996. ISBN 3-89518-075-0.

Lomborg, B. (2009). Global Crises, Global Solutions. Second Edition, Cambridge University Press, Cambridge (UK) 2009. ISBN 978-0-521-74122-4. https://doi.org/10.1017/cbo9780511807633

Pearce, D., Atkinson, Giles., \& Mourato, S. (2006): Cost-benefit Analysis and the Environment - Recent Developments. OECD Publishing, Paris (France) 2006. ISBN 92-64-01004-1.

Sachs, J. D. (2005). The End of Poverty - Economic Possibilities for Our Time. Penguin Press, a member of Penguin Group Inc., USA 2008. ISBN 978-0-14-303658-6.

Schabbel, C. (2007). The Value Chain of Foreign Aid - Development, Poverty Reduction, and Regional Conditions. Physica-Verlag, Heidelberg (Germany) 2007. ISBN 978-3-7908-1931-1.

Squire, L., / van der Tak, H. G. (1975): Economic Analysis of Projects - A World Bank Research Publication. Published for the World Bank. The Johns Hopkins University Press, Baltimore, Maryland 21211 (USA) 1975. ISBN 0-8018-1818-4.

\section{Internet}

BusinessDictionary (2015): Performance. URL:

http://www.businessdictionary.com/definition/performance.html

(call on 2015/02/10). 
BusinessDictionary (2014): Recurring Cost. URL:

http://www.businessdictionary.com/definition/recurring-cost.html

(call on 2014/10/06).

Investopedia (2014): Cost of Capital. URL:

http://www.investopedia.com/terms/c/costofcapital.asp

(call on 2014/10/06).

Investopedia (2014): NPV. URL:

http://www.investopedia.com/terms/n/npv.asp

(call on 2014/10/03).

Investopedia (2014): PV. URL:

http://www.investopedia.com/terms/p/presentvalue.asp

(call on 2014/10/03).

Least Developed Countries (2014): Definition of LDCs. URL:

http://www.ldcountries.org/definition_of_ldcs

(call on 2014/08/16).

nef - economics as if people and the planet mattered (2011): Social Return on Investment. URL:

http://www.neweconomics.org/projects/social-return-investment

(call on 2011/06/11).

Projektmagazin (2014): Net Present Value. URL:

https://www.projektmagazin.de/glossarterm/net-present-value

(call on 2014/03/07).

The SROI Network (2014): The Guide in English 2012 Edition. URL:

http://www.thesroinetwork.org/publications/cat_view/29-the-sroi-guide/223-the-guide-in-english-2012-edition

(call on 2014/09/22).

The SROI Network (2014): What is SROI? URL:

http://www.thesroinetwork.org/what-is-sroi

(call on 2014/09/22).

The SROI Primer (2011): Measuring Social Impact: The Foundation of Social Return on Investment [SROI]. URL:

http://sroi.london.edu/

(call on 2011/06/11).

UNCTAD (2014): Data on Least Developed Countries. URL:

http://unctadxiii.org/en/Documents/uxiiibook_08_LDCs.pdf

(call on 2014/08/16).

United Nations Development Programme (2011): Millennium Development Goals. URL:

http://www.undp.org/mdg/basics.shtml

(call on 2011/06/04).

United Nations Development Programme (2011): The 2010 MDG Summit Outcome. URL:

http://www.undp.org/mdg/summit.shtml

(call on 2011/06/23).

World Press (2006): Implementation Completion and Results Report-Guidelines. URL: http://nvardmanasian.files.wordpress.com/2011/02/icrguidefinalaug_2006.pdf

(call on 2014/02/15).

\section{Copyrights}

Copyright for this article is retained by the author(s), with first publication rights granted to the journal.

This is an open-access article distributed under the terms and conditions of the Creative Commons Attribution license which permits unrestricted use, distribution, and reproduction in any medium, provided the original work is properly cited. 